\title{
Synanthropic Clogmia albipunctata Causing Urogenital and Gastrointestinal Myiasis
}

\section{Ürogenital ve Gastrointestinal Miyazise Neden Olan Sinantropik Clogmia albipunctata}

(1) Didem Gökçe

Inonu University Faculty of Art and Science, Department of Biology, Malatya, Turkey

Cite this article as: Gökçe D. Synanthropic Clogmia albipunctata Causing Urogenital and Gastrointestinal Myiasis. Turkiye

Parazitol Derg 2020;44(3):182-4.

\begin{abstract}
Being a synanthropic cosmopolitan fly of tropical origin, Clogmia albipunctata is an aquatic species that is commonly found in moisture-rich places such as inside a house, sewage treatment plants, and hospitals. C. albipunctata can cause urogenital, intestinal, and even nasopharyngeal accidental myiasis under non-hygienic conditions or if a person consumes substandard food. Its larvae enter the human body via bodily cavities such as rectum, genitalia, or urinary canal, thereby leading to the development of infestation. This can in turn cause haematuria, bloody stool, vomiting and fever, with the appearance of larvae in urine and faeces. Here, we present the case of a 43-year-old woman with infection in the urogenital and gastrointestinal systems by the fourth instar larvae of $C$. albipunctata. To the best of our knowledge, this is the first report of myiasis caused by this species in Turkey. This study will provide general information about the biology of this species and methods to recognize it.
\end{abstract}

Keywords: Myiasis, Clogmia albipunctata, diptera, Turkey

ÖZ

Tropikal kökenli, sinantropik ve kozmopolit bir sinek olan Clogmia albipunctata; evler, kanalizasyon arıtma tesisleri ve hastaneler gibi çok fazla nem içeren yerlerde yaygın olarak bulunan sucul bir türdür. C. albipunctata, hijyenik olmayan koşullarda üretilen ve standartlara uygun olmayan yiyecekler tüketildiğinde ürogenital, bağırsak ve hatta nazofarenks bölgesinde beklenmedik şekilde miyazise neden olabilir. Rektal, genital ve idrar kanalı gibi vücut boşluklarına larvaların yerleşmesi ile gelişebilir ve sonuç olarak larvaların idrar ve dışkıda ortaya çıkmasıyla hematüri, kanlı dışkı, kusma ve ateşe neden olabilir. Bu çalışmada, ürogenital ve gastrointestinal sistemlerinin dördüncü evre C. albipunctata larvalarıyla enfekte olduğu 43 yaşındaki bir kadın olgu sunulmuştur. Bildiğimiz kadarıyla, bu türün Türkiye'de neden olduğu ilk miyazis raporudur. Bu çalışma, türün tanınması ve biyolojisi hakkında genel bilgi vermektedir.

Anahtar Kelimeler: Miyazis, Clogmia albipunctata, diptera, Türkiye

\section{INTRODUCTION}

Myiasis is defined as the infestation of tissues and organ cavities of human and vertebrate animals by Diptera larvae and the lesions develop as a result of feeding of these larvae with live or dead tissues, bodily fluids, or undigested food $(1,2)$. It is classified under three main types: obligatory, facultative, and accidental myiasis (1-4). Accidental myiasis is most often the result of ingesting larva-contaminated food, or develops when a fly deposits its eggs in a person's anus or urogenital area, whereupon the larvae then make their way into the rectum or urogenital canal. Additionally, most ingested larvae are unable to complete their life cycle in the human digestive or urogenital systems.

Patients who suffer from urogenital and intestinal myiasis complain of dysuria, polycoria, hematuria, nausea, and vomiting (1-5). Such complaints are known to develop due to the inflammatory reactions induced by the larvae. Toxins secreted by the larvae cause inflammation, prevent healing, and thus result in pathogenicity $(6,7)$.

\section{Received/Geliş Tarihi: 02.03.2020 Accepted/Kabul Tarihi: 11.05.2020}

Address for Correspondence/Yazar Adresi: Didem Gökçe, Inonu University Faculty of Art and Science, Department of Biology, Malatya, Turkey 
Cases of myiasis involving different tissues and cavities of various insects have been recorded in Turkey $(1,4,5,7)$. The aim of the present study is to report the first case of human urogenital and intestinal myiasis caused by Clogmia albipunctata (Diptera: Psychodidae) in Turkey.

\section{CASE REPORT}

A 43-year-old woman applied to the hospital complaining of that larvae were observed in her urine and feces for two months. The patient did not report that she suffered from fever, nausea, vomiting, abdominal pain, hematuria, hemorrhagic stool, or colporrhea during this period. However, she had complaints of peri-anal and periurethral-genital itching.

The patient is residing in the city center Malatya and has never travelled outside this city before. The patient confirmed that small flies were in her bathroom. It is likely that she was infected either while taking a shower or while cleaning her urogenital and anal areas with contaminated water. Her myiasis infection had continued in these areas -which are humid and rich in organic matter- until the larvae had completed pre-pupation period. During this period, the patient had expelled a total of 15 larvae. The patient was treated with antibiotic treatments and recommended to consume a diet rich in fiber and protein as well as plenty of water in order to dispel these larvae from her urinary and intestinal tracts.

In the laboratory, the larvae obtained from her urine and feces samples were washed carefully several times using distilled water and preserved in $80 \%$ ethyl alcohol. They were examined under a stereomicroscope, photographed, measured (Leica MZ 7.5 with DFC 280 camera attachment - Leica Applications Suite software, Version 2.4.0R1), and then identified according to Kvifte and Wagner (8).

The larvae were identified to be fourth instar larval stage (prepupation level) of C. albipunctata (bathroom fly). C. albipunctata Williston, 1893, belongs to the Psychodidae family and is aquatic in the larval stage. In the fourth instar stage, each larva has 26 pseudo-segments (annuli), a light-brown color and a bristly body. Their body has well-sclerotized tergal thoracic and abdominal plates (Figure 1), the former being slightly bilobed (Figure 2). Their head capsule is completed and prothoracic spiracles are present

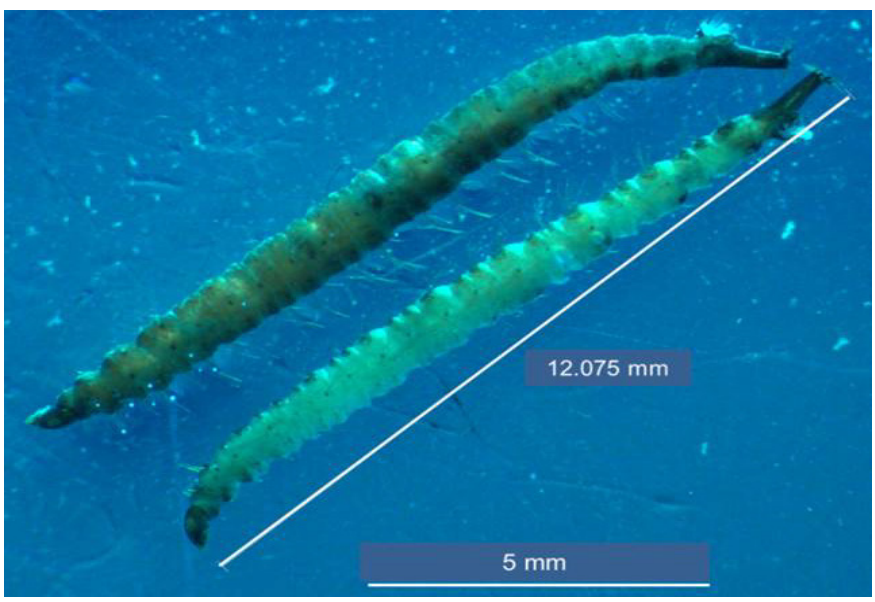

Figure 1. The bristly larval body of C. albipunctata fourth instar larvae (original)
(Figure 2). Their hypostoma contains three sharp teeth (Figure 3). Their respiratory siphon and the well-developed preanal plate are located in the post-abdominal segment (Figure 4).

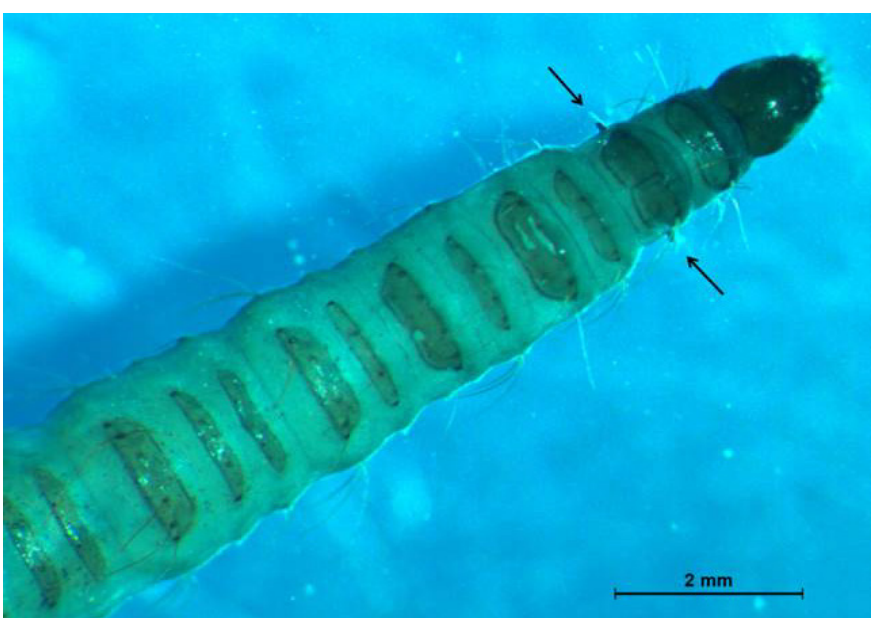

Figure 2. The sclerotised bilobed tergal thoracic and abdominal plates and prothoracic spiracles (original)

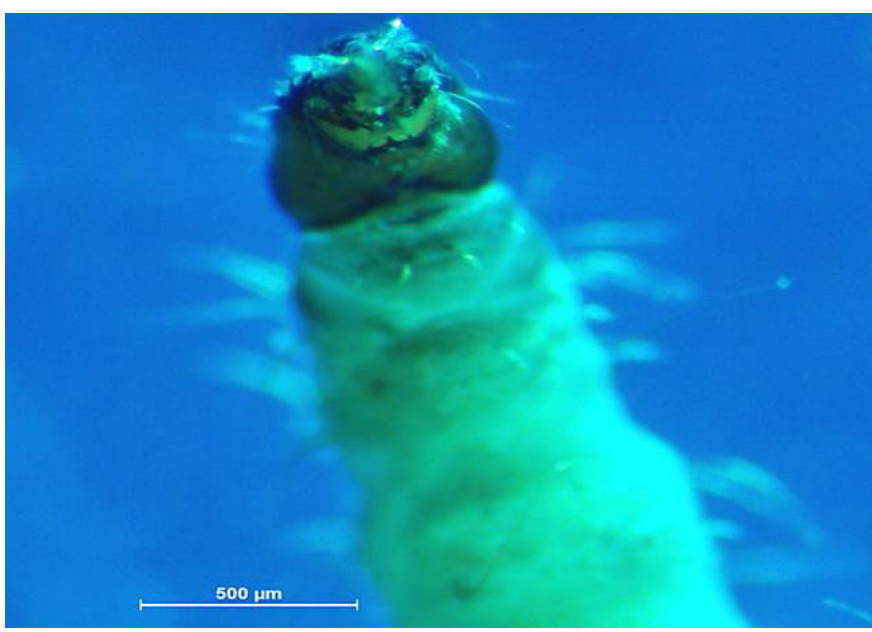

Figure 3. The hypostoma with three teeths in the chewing mouth of $C$. albipunctata fourth instar larvae (original)

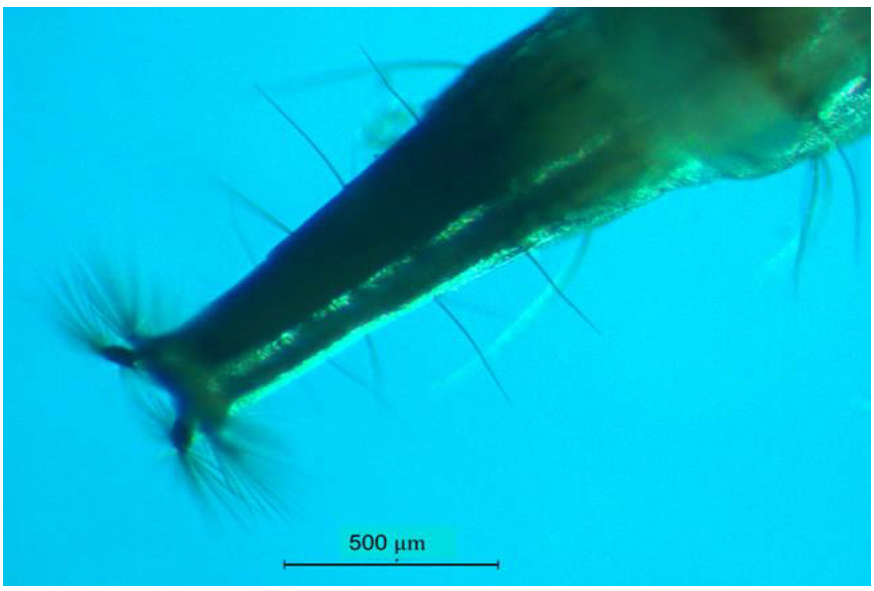

Figure 4. The post abdominal respiratory siphon of $C$. albipunctata fourth instar larvae (original) 


\section{DISCUSSION}

The family Psychodidae (Diptera) is divided into six subfamilies, one of which is Psychodinae- whose larvae are mostly aquatic (9). The taxonomic nomenclature of Psychodinae is complex, multiple synonyms for the same species exist, and therefore meaning that it remains controversial $(8,10)$. While the term $C$. albipunctata Williston, 1893 has long been accepted as a synonym of Psychoda albipunctata, the family revision has led to class this species under genus Clogmia Enderlein 1937. Currently, Clogmia is an accepted synonym of Telmatoscopus Eaton 1904; whereas, C. albipunctata is accepted as the valid species name taxonomy (11).

Psychodinae have a four-stage life cycle: egg, four larval instars, pupa, and adult. Larval growth time can vary based on temperature and the presence of nutrients (2). Increasing temperatures and continuously aquatic/humid environments accelerate their growth.

It takes approximately seventeen days for the growth period of $C$. albipunctata from egg to adult. An adult lives for approximately ten days, depending on the ambient temperature. New adults become sexually mature within about ten hours; both genders can mate and reproduce with more than one individual from the other gender. A female can lay 200 to 300 eggs $(10,12)$. Adults have non-functional mouthparts, and therefore do not feed. Larvae, on the other hand, are both coprophagous and saprophagous and have mouthparts capable of chewing.

The subfamily Psychodinae has previously been recorded in the Nearctic, Oriental, and Australian zoogeographic regions (9). C. albipunctata have been recorded in Europe since the 1990s and are likely to have been transported from tropical areas via exported fruit and vegetables that were contaminated (13).

C. albipunctata has been reported to have caused urinary, intestinal and nasopharyngeal myiasis in cases from European countries such as Russia, as well as from Palestine and Japan $(2,11,14)$. In Turkey, C. albipunctata has been reported to be seen in aquatic and semi aquatic habitats across western Anatolia (14), however there has been no Turkish case of myiasis.

In urogenital myiasis, larvae are excreted from the urinary tract with the mechanical washing effect of urine. Similarly, the larvae in the gastrointestinal system are excreted from feces through the peristaltic movements of the intestine.

In poor socio-economic conditions and hygiene, myiasis and infection with microorganisms are potential factors because flies can transmit many microorganism or parasitic infections (15). Unhygienic conditions and substandard food may increase the risk of urogenital and intestinal myiasis.

\section{* Ethics}

Informed Consent: Patient consent was not obtained, as only parasites were examined in this study case.
Peer-review: Internally peer-reviewed.

Financial Disclosure: This research did not receive any specific grant from funding agencies in the public, commercial, or not-forprofit sectors.

\section{REFERENCES}

1. Karabiber H, Gökçe-Oğuzkurt D, Dogan DG, Aktas M, Selimoglu MA. An unusual cause of rectal bleeding: intestinal myiasis. J Pediatr Gastroenterol Nutr 2010; 51: 530-1.

2. Farrag HMM, Huseein EAM, Almatary AM, Othman RA. Morphological and initial molecular characterization of Clogmia albipunctatus larvae (Diptera: Psychodidae) causing urinary myiasis in Egypt. PLoS Negl Trop Dis 2019; 13: e0007887.

3. Dagci H, Zeyrek F, Gerzile YK, Sahin SB, Yagci S, Uner A. A case of myiasis in a patient with psoriasis from Turkey Parasitol Int 2008; 57: 239-41.

4. Şahin AR, Ölker U, Nazik S, Güler S, Kireççi E. Urogenital myiasis caused by Psychoda albipennis. Turkiye Parazitol Derg 2018; 42: 93-5.

5. Beyhan YE, Yılmaz H, Baran Aİ, Cengiz ZT, Yakan U, Ekici A. Urogenital myiasis caused by Psychoda albipennis (Diptera: Psychodidae) in a woman in Siirt. Turkiye Parazitol Derg 2015; 39: 316-8.

6. El-Badry AA, Salem HK, El-Aziz Edmardash Y. Human urinary myiasis due to larvae of Clogmia (Telmatoscopus) albipunctata Williston (Diptera: Psychodidae) first report in Egypt. J Vector Borne Dis 2014; 51: 247-9.

7. Önder Z, İnci A, Ylldırım A, Çiloğlu A, Düzlü O. Molecular characterization of myiasis-causing moth flies (Diptera: Psychodidae). Turkiye Parazitol Derg 2018; 42: 223-8

8. Kvifte GM, Wagner R. Psychodidae (Sand Flies, Moth Flies or Owl Flies). Suricata 2017; 5: 607-32.

9. Wagner R, Barták M, Borkent A, Courtney G, Goddeeris B, Haenni J-P, et al. Global diversity of dipteran families (Insecta Diptera) in freshwater (excluding Simuliidae, Culicidae, Chironomidae, Tipulidae and Tabanidae). Hydrobiologia 2008; 595: 489-519.

10. Boumans L, Zimmer J-Y, Verheggen F. First records of the "bathroom mothmidge" Clogmia albipunctata, a conspicuous element of the Belgian fauna that went unnoticed (Diptera: Psychodidae). Phegea 2009; 37: 15360.

11. Faridnia R, Soosaraei M, Kalani H, Fakhar M, Jokelainen P, Emameh RZ, et al. Human urogenital myiasis: A systematic review of reported cases from 1975 to 2017. Eur Jour Obst Gynecol Rep Biol 2019; 235: 57-61.

12. Zittra C, Schoener ER, Wagner R, Heddergott M, Georg G. Duscher GG, et al. Unnoticed arrival of two dipteran species in Austria: the synanthropic moth fly Clogmia albipunctata (Williston, 1893) and the parasitic bird louse fly Ornithoica turdi (Olivier in Latreille, 1811). Parasitol Res 2020; 119: 737-40.

13. Hovius JW, Wagner R, Ziegler J, Mehlhorn H, M.P. Grobusch MP. A hairy problem. Neth J Med 2011; 69: 531-4.

14. Wagner R, Koç H, Özgül O, Tongu A. New moth flies (Diptera: Psychodidae: Psychodinae) from Turkey. Zool Middle East 2013; 59: 152-67.

15. Faulde M, Spiesberger M. Role of the moth fly Clogmia albipunctata (Diptera: Psychodinae) as a mechanical vector of bacterial pathogens in German hospitals. J Hosp Infect 2013; 83: 51-60. 